\begin{tabular}{cc|c}
\hline Tar. Bil. Der. & Journal of Agricultural Sciences \\
& $\begin{array}{c}\text { Dergi web sayfası: } \\
\text { www.agri.ankara.edu.tr/dergi }\end{array}$ & Journal homepage: \\
& www.agri.ankara.edu.tr/journal
\end{tabular}

\title{
Effects of Additive Intercropping on Mineral Uptake of Onion and Fenugreek at Different Densities
}

\author{
Tahereh MOGHBELI ${ }^{\mathrm{a}}$, Sahebali BOLANDNAZAR ${ }^{\mathrm{a}}$, Jaber PANAHANDE ${ }^{\mathrm{a}}$, Yaegoob RAEI ${ }^{\mathrm{b}}$ \\ ${ }^{a}$ University of Tabriz, Faculty of Agriculture, Department of Horticulture, Tabriz, IRAN

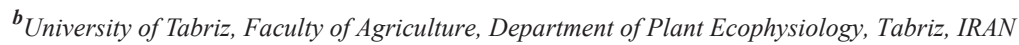

\section{ARTICLE INFO}

Research Article

DOI: 10.15832 ankutbd.404926

Corresponding Author: Sahebali BOLANDNAZAR, E-mail: sbolandnazar@gmail.com, Tel: + 98 (413) 3392021

Received: 20 March 2018, Received in Revised Form: 07 July 2018, Accepted: 01 September 2018

\begin{abstract}
Increasing world population demands for food, limited natural resources have created the risk of food security for current and future generations. Intercropping is regarded as an effective strategy in sustainable agriculture. Therefore, current study was carried out to evaluate the nutrient uptake of onion and fenugreek intercropping system during two growing season of (2015-2016 and 2016-2017) at a research field in Kerman, Iran. Two factorial experiments based on completely random blocks design with three replications were carried out. The treatments in this study were including: onion densities as the first factor $\left(30,25\right.$ and 20 plants $\left.\mathrm{m}^{-2}\right)$ and fenugreek densities as the second factor at three levels of 25,15 and 12 plants $\mathrm{m}^{-2}$ with sole cropping of two species at these densities. Results showed that in the both of years, mineral concentration and uptake (N, P and K) of onion leaf and bulb and fenugreek in intercropping increased in comparison with mono cropping for two species. In both years, the highest and lowest nutrient content of onion was observed in the densities of 30 and 20 plant $\mathrm{m}^{-2}$. In general, it can be said that intercropping systems have some positive effects on nutrient content and uptake of onion.
\end{abstract}

Keywords: Fenugreek; Intercropping; Nutrient content; Onion; Plant nutrient uptake

(C) Ankara Üniversitesi Ziraat Fakültesi

\section{Introduction}

Onion (Allium cepa L.) is an important economic vegetable crop which unique flavor is appreciated by people in every part of the world. Also, it is one of the most prominent commercial vegetable crop grown in Iran and thought to be originated in central Asia (Anthon \& Barrett 2003). Having high mineral and organic contents, onions are essential for human health (Raj \& Yadav 2005). It has low branched roots, so needs to supply adequate minerals. Intercropping onion with legumes have some advantages as follows: improved nutrient availability, soil structure, hormonal effects and reduced pest and disease incidence through rhyzodeposition. Fenugreek (Trigonella foenugraecum L.) is an annual crop from Leguminosae, being used as condiment and dried leaves to prepare spice. The vegetative parts are also rich in vitamins A, B and iron. In addition to fixing nitrogen, forming a cover on the soil surface, it hinders weeds growth and diminishes soil erosion (Basch et al 2003). 
Intercropping is a crop management system which involves two or more economic species grown together for at least a part of their respective productive cycle and planted sufficiently close to each other, so that inter-specific competition can occur (Ouma \& Jeruto 2010). The main advantage of intercropping is the more effective usage the available resources, reduced the nutrients leaching, keeping the soil fertility and enhanced productivity as compared the sole crop cultivation (Lithorgidis et al 2011). A significant reason for intercropping is the improvement and maintenance of soil fertility and increasing the productivity per unit of land (Pozdíšek et al 2011). Intercropping enhances soil fertility via biological nitrogen fixation of legumes, improves the soil protection through more ground cover than sole cropping, and provides better lodging resistance for crops vulnerable to lodging than when grown in monoculture (Ouma \& Jeruto 2010). A legume, grown in associated to other crop, especially with a cereal, have normally more productivity in cropping systems (Kamran Khan et al 2015). Thus modern farming system intercropping implies a key strategy for sustainable agriculture (Jackson et al 2007). Intercropping is a way to introduce more biodiversity into agro-ecosystems and the results obtained from intercropping studies indicate that increased crop diversity could increase the number of ecosystem services provided (Lithourgidis et al 2011). Enhancing productivity via more effective use of available resources (light, water, fertilizer, etc.) is possible through intercropping which leads to diminished weed pressure and plant health protection (Hauggaard-Nielsen et al 2003; Banik et al 2006).

Inorganic nutrients including nitrogen $(\mathrm{N})$, phosphorus $(\mathrm{P})$ and potassium $(\mathrm{K})$ are fundamental macronutrient for growth and development of all living organisms. Being absorbed in large amounts, nitrogen contributes significantly to raise the onion production (Myaka et al 2006). Phosphorus plays a vital role in cellular energy transfer, respiration, photosynthesis and root development (Alam et al 2016). In soils which are contain moderately low $\mathrm{P}$, onion growth and yield can increase by applied
P. The beneficial effect of potassium can be found in different traits of agricultural products, such as photosynthesis, translocation of photosynthesis, regulation of plant, activation of plant catalysts and resistance against pests and disease (Malavolta 2006). There are many studies demonstrating the superiority of intercropping legumes include intercropping wheat with soybean (Lithourgidis et al 2011), wheat with fenugreek (Wasaya et al 2013) and maize with soybean (Owusu \& Sadick 2016). Also intercropping of legume crop (pigeon pea) in maize added up about $60 \mathrm{~kg} \mathrm{~N} \mathrm{ha}^{-1}$ and improves the fertility status of soil (Myaka et al 2006). Therefore, the objective of this study was to evaluate the intercropping system effect and density on plant nutrient concentration and uptake of onion and fenugreek.

\section{Material and Methods}

Two experiments were conducted during two successive growing seasons (2015-2016 and 20162017) in Agricultural Research Center; Kerman, Iran. ( $31^{\circ} 7^{\prime} \mathrm{N}, 57^{\circ} 14^{\prime} \mathrm{E}$ and $\left.1749 \mathrm{MASL}\right)$. Some properties of soil were shown in Table 1. A factorial set of treatments was arranged within completely randomized blocks design (RCBD) with three replications. Intercropping pattern was additive series. The first factor was three onion distance $(8$, 10 and $12 \mathrm{~cm}$ ) for densities $(300000,250000$ and 200000 plant ha $^{-1}$ ), and the second factor comprised of fenugreek distance $(10,15$ and $20 \mathrm{~cm})$ for plant populations of 250000, 150000 and 120000 plant ha $^{-1}$ in both intercropping and mono cropping system. Fertilization was done according to soil analysis results and nutritive requirement of species. Any insect, pest and disease infections were not seen in the experimental field. In the present study, onion seed cv. 'Rossen' were planted in nursery, onions forty-five day old onion seedlings and fenugreek seeds were planted in the right side and fenugreek seed was sown in the opposite side of rows, by hand in December 2015 and September 2016 in intercropping treatment. Each single crop in the mono treatments was cultivated in the same site of lateral. All other agronomic operations except 
those under study were kept normal and uniform for all treatments. The fenugreek was harvested when plants reached the peak of vegetative growth, with marketable 2 and 4 month after planting before flowering. Onion bulbs were harvested 4 month after transplanting (when $80 \%$ of onion leaves had fallen). At maturity, five plants from each plot were collected randomly to determine parameters. The plant sample (leaf and bulb) of onion and (shoot) of fenugreek were collected from each plot and were dried for $48 \mathrm{hrs}$ in hot air oven at $65 \pm 5{ }^{\circ} \mathrm{C}$. Finally ground samples were passed through $0.5 \mathrm{~mm}$ mesh sieve and were used for chemical determination of nitrogen, phosphorus and potassium. The concentrations of potassium and phosphorus were determined by nitric perchloric and nitric acid digestion methods. Phosphorus was measured by the vanadate- molybdate method using a spectrophotometer HITACHI U-1100 at wavelengths of $430 \mathrm{~nm}$ and nitrogen was measured by the spectrophotometer HITACHI U-1100 at wavelengths of $650 \mathrm{~nm}$ that involved changing the form of organic nitrogen to the ammonium $\left(\mathrm{NH}^{+}\right)$ form with concentrated sulfuricacid and then measuring the amount of ammonium production (Baethgen \& Alley 1989), and K was determined using a flame photometer (Model 405G) methods described by (Cottenie 1980).

Nutrient uptake $=$ Nutrients contents $(\mathrm{mg}) \times$ Dry weight $(\mathrm{g})$

Statistical analysis: Analyses of variance were applied to the data using SAS (Statistical Analysis System) version 9.1. And Excel software was used to draw figures. Then, means were compared by Duncan's multiple range test.

\section{Results and Discussions}

A: Onion, According to the results, the year effect on nutrient concentration and uptake was significant $(\mathrm{P}<0.01)$ (Table 2$)$. In the first year, leaf and bulb concentrations $(\mathrm{N}, \mathrm{P}, \mathrm{K})$ of nutrient in onion were higher than the second year (Table 3 ). In the second year, nutrient uptakes were higher than the first. Average temperature and rainfall data (Table 4) clearly show that in the second year, high temperatures at the early planting of onion affected on root growth and morphology of plants, and resulted in higher nutrient uptake by onions. Soil temperature has long been thought as a prominent ecological factor which determines a variety of structural and functional characteristics in managed and natural ecosystems. In some ecosystems, the root zone temperature is the most important factor in determining net primary productivity (Risser 1985). Soil thermal regime has a dramatic effect on root growth and morphology. (Camilia 2001) discovered that the mineral status depends on some environmental factors including temperature, rainfall, parent material, plant species, and fertilization practice. The exact mechanism for temperature-induced changes in nutrient uptake capacity is not clearly understood. Root-zone temperature might affect nutrient absorption capacity by changing fluidity of the fatty acids in root plasmalemma. The most notable are the direct effects of soil temperature on biogeochemical processes that regulate $\mathrm{N}$ and water availability in the soil (Parsons et al 1994).

Nutrients concentration ( $\mathrm{N}, \mathrm{P}$, and $\mathrm{K})$ : The effects of onion and fenugreek densities on $\mathrm{N}, \mathrm{P}$ and $\mathrm{K}$ concentration were significant $(\mathrm{P} \leq 0.01)$ and $(\mathrm{P} \leq 0.05)$. Nutrients concentration in leaf was

Table 1- Some physicochemical properties of soil before sowing (depth: 0-30 cm) in 2015-2016 and 20162017 seasons

\begin{tabular}{ccccccccccc}
\hline Years & Texture & Sand & Silt & Clay & $\begin{array}{c}\text { Organic carbon } \\
(\%)\end{array}$ & $p H$ & $\begin{array}{c}E C \\
\left(\mathrm{dSm}^{-1}\right)\end{array}$ & $\begin{array}{c}\text { Total N } \\
(\%)\end{array}$ & $\begin{array}{c}P \\
\left(\mathrm{mg} \mathrm{kg}^{-1}\right)\end{array}$ & $\begin{array}{c}K \\
\left(\mathrm{mg} \mathrm{kg}^{-1}\right)\end{array}$ \\
\hline $2015-2016$ & loam & 45.72 & 28.88 & 25.40 & 0.41 & 7.60 & 1.30 & 0.02 & 8.40 & 175 \\
$2016-2017$ & loam & 46.20 & 28.20 & 25.60 & 0.23 & 7.90 & 1.26 & 0.03 & 9.40 & 200 \\
\hline
\end{tabular}


Table 2- Analysis of variance of intercropping onion and fenugreek on mineral concentration and uptake by plant

\begin{tabular}{lllllllllll}
\hline $\begin{array}{l}\text { Source of } \\
\text { variation }\end{array}$ & df & \multicolumn{9}{c}{ Concentration } \\
\cline { 3 - 10 } & NLeaf & NBulb & PLeaf & PBulb & KLeaf & KBulb & $N$ & $P$ & $K$ \\
\hline Year (y) & 1 & $1.200^{* *}$ & $3.900^{* *}$ & $0.060^{* *}$ & $0.920^{* *}$ & $5.12^{*}$ & $5.03^{* *}$ & $52093.17^{* *}$ & $1133.09^{* *}$ & $131659.00^{*}$ \\
Error & 4 & 0.040 & 0.130 & 0.017 & 0.002 & 0.55 & 1.25 & 276.50 & 7.11 & 530.90 \\
Onion (A) & 2 & $0.660^{* *}$ & $0.110 \mathrm{~ns}$ & $0.017^{*}$ & $0.019^{*}$ & $1.22^{*}$ & $4.85^{* *}$ & $820.65^{* *}$ & $48.49^{* *}$ & $4855.20^{* *}$ \\
Fenugreek(B) & 3 & $0.450^{* *}$ & $0.820^{* *}$ & $0.110^{* *}$ & $0.037^{* *}$ & $8.74^{* *}$ & $5.51^{* *}$ & $454.60^{*}$ & $10.32^{*}$ & $2058.60^{*}$ \\
$\mathrm{~A} \times \mathrm{B}$ & 6 & $0.070 \mathrm{~ns}$ & $0.070 \mathrm{~ns}$ & $0.003 \mathrm{~ns}$ & $0.009 \mathrm{~ns}$ & $0.96 \mathrm{~ns}$ & $0.39 \mathrm{~ns}$ & $310.85 \mathrm{~ns}$ & $7.94 \mathrm{~ns}$ & $598.70 \mathrm{~ns}$ \\
$\mathrm{Y} \times \mathrm{A}$ & 2 & $0.011 \mathrm{~ns}$ & $0.006 \mathrm{~ns}$ & $0.001 \mathrm{~ns}$ & $0.006 \mathrm{~ns}$ & $0.40 \mathrm{~ns}$ & $0.11 \mathrm{~ns}$ & $11.06 \mathrm{~ns}$ & $4.77 \mathrm{~ns}$ & $247.80 \mathrm{~ns}$ \\
$\mathrm{Y} \times \mathrm{B}$ & 3 & $0.010 \mathrm{~ns}$ & $0.160 \mathrm{~ns}$ & $0.006 \mathrm{~ns}$ & $0.029^{* *}$ & $1.25^{*}$ & $0.03 \mathrm{~ns}$ & $244.49 \mathrm{~ns}$ & $4.33 \mathrm{~ns}$ & $1474.40^{*}$ \\
$\mathrm{Y} \times \mathrm{A} \times \mathrm{B}$ & 6 & $0.010 \mathrm{~ns}$ & $0.060 \mathrm{~ns}$ & 0.003 & $0.010 \mathrm{~ns}$ & $0.26 \mathrm{~ns}$ & $0.20 \mathrm{~ns}$ & $440.43 \mathrm{~ns}$ & $9.36 \mathrm{~ns}$ & $264.00 \mathrm{~ns}$ \\
Error & 44 & 0.060 & 0.080 & 0.004 & 0.005 & 0.43 & 0.92 & 229.36 & 4.90 & 387.30 \\
$\mathrm{Cv}(\%)$ & & 5.770 & 8.730 & 9.480 & 15.390 & 9.22 & 25.69 & 19.43 & 17.60 & 18.30 \\
\hline
\end{tabular}

*,**, significant at $\mathrm{P} \leq 0.05, \mathrm{P} \leq 0.01$ respectively; ns, not significant

Table 3-The effect of years on mineral concentration and total mineral uptake of onion

\begin{tabular}{|c|c|c|c|c|c|c|c|c|c|c|c|c|}
\hline \multirow{2}{*}{ Seasons } & \multicolumn{6}{|c|}{ Concentration $\left(\mathrm{mg} \mathrm{g}^{-1} \mathrm{DW}\right)$} & \multicolumn{3}{|c|}{ Uptake (mg DW plant $\left.{ }^{1}\right)$} & \multicolumn{2}{|c|}{ Uptake $\left(\mathrm{kg} \mathrm{ha}^{-1}\right)$} & \multirow[b]{2}{*}{$\mathrm{K}$} \\
\hline & $N$ Leaf & N Bulb & P Leaf & P Bulb & K Leaf & $u l b$ & $N$ & $P$ & $K$ & $N$ & $P$ & \\
\hline & $4.50 \mathrm{a}$ & $3.52 \mathrm{a}$ & $070 \mathrm{~h}$ & $060 \mathrm{a}$ & $7.37 \mathrm{a}$ & 401 & 51. & 86 & $\mathrm{~b}$ & 15 & 2.6 & 20 \\
\hline $\mathrm{Y}_{2}$ (year) & $4.24 \mathrm{~b}$ & $3.05 \mathrm{~b}$ & $0.76 \mathrm{a}$ & $0.38 \mathrm{~b}$ & $6.84 \mathrm{~b}$ & $3.48 \mathrm{~b}$ & $104.83 \mathrm{a}$ & $16.55 \mathrm{a}$ & $150.10 \mathrm{a}$ & $28.34 \mathrm{a}$ & $4.48 \mathrm{a}$ & $40.57 \mathrm{a}$ \\
\hline
\end{tabular}

Means with similar letter in each column are not significantly $(\mathrm{P}<0.05)$ different by Duncan Multiple Range test

Table 4- Average temperature and rainfall during growth seasons

\begin{tabular}{lcclcc}
\hline \multicolumn{3}{c}{$2015-2016$} & \multicolumn{2}{c}{ 2016- 2017} \\
\hline Date & Temperature $\left({ }^{\circ} \mathrm{C}\right)$ & Rainfall $(\mathrm{mm})$ & Date & Temperature $\left({ }^{\circ} \mathrm{C}\right)$ & Rainfall $(\mathrm{mm})$ \\
\hline December & 13.5 & 59.8 & September & 29.2 & 0.0 \\
January & 13.7 & 0.2 & October & 22.4 & 0.0 \\
February & 19.6 & 4.0 & November & 16.0 & 8.3 \\
March & 24.8 & 7.6 & December & 15.0 & 0.0 \\
April & 29.7 & 0.8 & January & 13.3 & 148.1 \\
\hline
\end{tabular}

decreased by increasing onion density (Table 2). $\mathrm{N}, \mathrm{P}$ and $\mathrm{K}$ maximum and minimum content in leaf were observed at densities of 20 and 30 plants $\mathrm{m}^{-2}$, respectively (Table 5). No significant difference observed in bulb $\mathrm{N}$ concentration among onion densities (Table 2). While, the highest and the lowest $\mathrm{P}$ and $\mathrm{K}$ concentration of leaf and bulb were recorded in densities of 20 and 30 onions per $\mathrm{m}^{2}$, respectively
(Table 5). Also, N, P and K concentration of bulb and leaf were increased by intercropping onion with fenugreek as this trait was more at various densities of fenugreek compared to onion mono cropping. However, the effect of various densities of fenugreek on $\mathrm{N}, \mathrm{P}$ and $\mathrm{K}$ concentration of bulb and leaf were statistically similar (Table 5). Also the interaction effect of year and fenugreek density had 
a significant effect on the $\mathrm{P}$ concentration of bulb and $\mathrm{K}$ concentration of leaf (Table 2). The lowest $\mathrm{P}$ concentration of leaf and bulb were obtained in density of 0 fenugreek (sole cropping of onion), while P concentration of bulb was increased by intercropping onion with fenugreek as this trait was more at various densities of fenugreek compared to onion mono cropping in the first year. However, the effect of various densities of fenugreek on $\mathrm{P}$ concentration of bulb was statistically similar in the second year (Figure 1). The highest concentration of $\mathrm{K}\left(8.24 \mathrm{mg} \mathrm{g}^{-1}\right.$ DW) was obtained under intercropping with 12 plants $\mathrm{m}^{-2}$ fenugreek in the first year, and the lowest concentration of $\mathrm{K}(5.78$ $\mathrm{mg} \mathrm{g}^{-1} \mathrm{DW}$ ) was observed in (sole cropping) of onion in the second year (Figure 2).

Nutrient Uptake: The effects of onion and fenugreek densities on nutrient uptake of onion were significant $(\mathrm{P} \leq 0.01)$ and $(\mathrm{P} \leq 0.05)$, respectively (Table 2). Increasing onion densities, nutrient uptake by plant was decreased. The maximum and the minimum uptake of nutrient were observed at densities of 20 and 30 plants $\mathrm{m}^{-2}$, respectively (Table 5). Also, nutrient uptake was increased by intercropping onion with fenugreek as this trait was more at various densities of fenugreek compared to onion mono cropping. However, the effect of various densities of fenugreek on nutrient uptake of onion

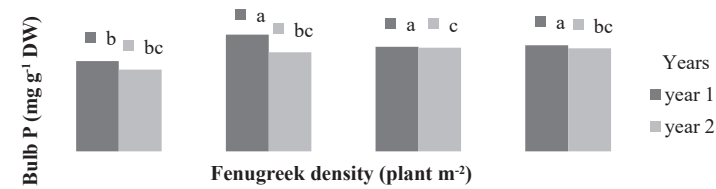

Figure 1- The interaction effect of year and fenugreek on $P$ concentration of onion bulb

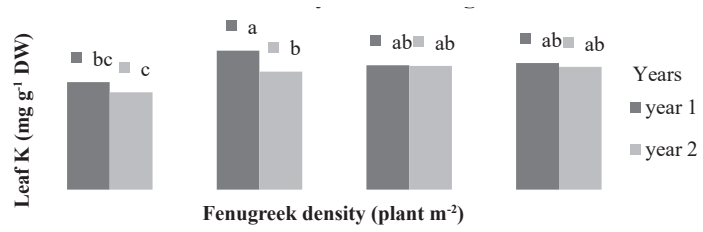

Figure 2- The interaction effect of year and fenugreek densities on $K$ concentration of onion leaf

was statistically similar. Also the interaction effect of year and fenugreek density on the $\mathrm{K}$ uptake was significant (Table 2), the highest (172.16 g plant $^{-1}$ ) was obtained under intercropping with 12 plants $\mathrm{m}^{-2}$ fenugreek in the second year, and the lowest $\mathrm{K}$ uptake was related to densities of 0 (sole cropping) onion and was statistically similar in the first year (Figure 3). The results show uptake $\mathrm{ha}^{-1}$ values (Table 6); high densities of two crops confirms to the highest uptake ha ${ }^{-1}\left(26.14,4.67\right.$ and $\left.38.02 \mathrm{~kg} \mathrm{ha}^{-1}\right)$ for $\mathrm{N}, \mathrm{P}$ and $\mathrm{K}$ recorded in combination treatment

Table 5- Effect of intercropping of onion and fenugreek on the mineral content and total mineral uptake of onion

\begin{tabular}{|c|c|c|c|c|c|c|c|c|c|}
\hline \multirow{2}{*}{$\begin{array}{c}\text { Density } \\
\text { (plants } m^{-2} \text { ) }\end{array}$} & \multicolumn{6}{|c|}{ Concentration $\left(\mathrm{mg} \mathrm{g}^{-1} \mathrm{DW}\right)$} & \multicolumn{3}{|c|}{ Uptake (mg DW Plant $\left.{ }^{-1}\right)$} \\
\hline & $N$ Leaf & N Bulb & P Leaf & P Bulb & KLeaf & K Bulb & $N$ & $P$ & $K$ \\
\hline \multicolumn{10}{|l|}{ 0nion } \\
\hline 30 & $4.27 \mathrm{~b}$ & $3.24 \mathrm{a}$ & $0.70 \mathrm{~b}$ & $0.46 \mathrm{~b}$ & $6.85 \mathrm{~b}$ & $3.26 \mathrm{~b}$ & $72.03 \mathrm{~b}$ & $11.17 \mathrm{c}$ & $92.98 \mathrm{c}$ \\
\hline 25 & $4.27 \mathrm{~b}$ & $3.25 \mathrm{a}$ & $0.73 \mathrm{ab}$ & $0.50 \mathrm{ab}$ & $7.20 \mathrm{ab}$ & $3.83 \mathrm{a}$ & $78.06 \mathrm{ab}$ & $12.56 \mathrm{~b}$ & $107.72 \mathrm{~b}$ \\
\hline 20 & $4.56 \mathrm{a}$ & $3.36 \mathrm{a}$ & $0.75 \mathrm{a}$ & $0.52 \mathrm{a}$ & $7.27 \mathrm{a}$ & $4.14 \mathrm{a}$ & $83.72 \mathrm{a}$ & $14.01 \mathrm{a}$ & $121.42 \mathrm{a}$ \\
\hline \multicolumn{10}{|l|}{ Fenugreek } \\
\hline 0 & $4.16 \mathrm{~b}$ & $2.97 \mathrm{~b}$ & $0.61 \mathrm{~b}$ & $0.44 \mathrm{~b}$ & $6.08 \mathrm{~b}$ & $2.92 \mathrm{~b}$ & $71.01 \mathrm{~b}$ & $11.78 \mathrm{~b}$ & $99.03 \mathrm{~b}$ \\
\hline 25 & $4.38 \mathrm{a}$ & $3.38 \mathrm{a}$ & $0.75 \mathrm{a}$ & $0.49 \mathrm{~b}$ & $7.38 \mathrm{a}$ & $4.10 \mathrm{a}$ & $77.87 \mathrm{ab}$ & $12.24 \mathrm{ab}$ & $108.15 \mathrm{ab}$ \\
\hline 15 & $4.50 \mathrm{a}$ & $3.33 \mathrm{a}$ & $0.77 \mathrm{a}$ & $0.48 \mathrm{~b}$ & $7.35 \mathrm{a}$ & $3.91 \mathrm{a}$ & $80.10 \mathrm{ab}$ & $12.78 \mathrm{ab}$ & $112.02 \mathrm{ab}$ \\
\hline 12 & $3.38 \mathrm{a}$ & $3.45 \mathrm{a}$ & $0.78 \mathrm{a}$ & $0.55 \mathrm{a}$ & $7.61 \mathrm{a}$ & $4.03 \mathrm{a}$ & $82.75 \mathrm{a}$ & $13.54 \mathrm{a}$ & $120.29 \mathrm{a}$ \\
\hline
\end{tabular}

Means with similar letter in each column are not significantly $(\mathrm{P}<0.05)$ different by Duncan Multiple Range test 
of 30: 25 plants $\mathrm{m}^{-2}$ onion and fenugreek at mean of two years, while the lowest uptake ha-1 (14.99, 2.63 and $22.11 \mathrm{~kg}$ ) for $\mathrm{N}, \mathrm{P}$ and $\mathrm{K}$ was found in sole cropping treatment with 20 plants $\mathrm{m}^{-2}$ (onion) density for mean of years. Soil nutrient which were absorbed by plant is a crucial resources for plant metabolism, especially to build cell structure and plant grows and development. Nutrient absorption in plant roots, therefore will be similar with the nutrient in plant tissue and it correlates positively with organic compound which was resulted from plant metabolism (Alam et al 2016). Onion is more vulnerable to nutrient shortages than most crop plants because of their shallow and unbranched root system; therefore, they cannot maintain adequate nutrients uptakeing such as phosphorous and potassium which are known to diffuse slowly through the soil solution (Brewester 1994). Different nutrients $(\mathrm{N}, \mathrm{P}$ and $\mathrm{K})$ uptaking by leaves and bulbs of onion influenced by intercropped fenugreek. In intercropping system, root interactions could raise the root extent and microbial activity in rhizosphere (Zhang et al 2013). Inter- specific interaction in rhizosphere compositely affects nutrient availability and uptaking in intercropping system (HauggardNielsen 2003; Li et al 2010). Intercropping onion with fenugreek increased the $\mathrm{N}, \mathrm{P}$ and $\mathrm{P}$ content in leaf and bulb and total uptake $\mathrm{N}, \mathrm{P}$ and $\mathrm{K}$. This was probably due to higher nitrogen fixation by the bacteria causing more utilization of all the nutrients by crop thus lead to more N, P and K content in leaf and bulb. Studies have presented advantages of intercropping with legumes including tomato with common bean (Abd El-Gaid et al 2014), Barely with fenugreek (Kamran Khan et al 2015), and wheat with fenugreek (Wasaya et al 2013). Nutrient uptake was significantly influenced by cropping systems where onion plants were more nutrient uptake in plots that had onion intercropped with fenugreek at wider spacing compared with other treatment. This could have been contributed by the fixed nitrogen which improved the plant nutrient uptake over other treatments. Although intercropping at narrower spacing also had fixed nitrogen, but the plant was strong completion which led to increase nutrient uptake (Table 5). Also, low densities of onion plant leads to reduction in competition between onion and fenugreek plants for resources and enhances soil fertility via atmosphere nitrogen fixation into the soil (150 tons year $\left.{ }^{-1}\right)$. Legumes increases soil conservation through more cover on ground than sole cropping (Oroka \& Omoregie 2007). Results indicated that maize and soybean intercropping caused an increase in phosphorus $\left(5.25 \mathrm{mg} \mathrm{kg}^{-1}\right)$ (Owusu \& Sadick 2016). (Zhang et al 2009) studied the effects of maize- peanut and stated that intercropping could increase soil bacteria in the both of maize and peanut root zones. Also, improved uptake of $\mathrm{N}, \mathrm{P}$ and $\mathrm{K}$ nutrients might be attributed to higher dry matter accumulation with density decrease leading to higher uptake of N, P and K. Similar results of increased uptake of N, $\mathrm{P}$ and $\mathrm{K}$ due to wider row spacing were reported by (Thavaprakaash \& Velayudham 2007) in baby corn. The increase in the onion density enhanced the uptake of plants ha ${ }^{-1}$ (leading to an increase in uptake). In general, the more $\mathrm{N}$ uptake, the more crop tendency to absorb more $\mathrm{P}$ and $\mathrm{K}$. This is similar to the findings of (Rathika 2013) in maize. (Gahoonia et al 2006) stated that plant nutrients such as $(\mathrm{K})$ and $(\mathrm{P})$ mostly remain fixed in soils and their bioavailability to plant roots is diffusion- limited. The increased uptake of nutrients is possibly due to higher photosynthetic rate and nitrate reductase activity led to better uptake of $\mathrm{N}$ by the crop. Generally, when the uptake of $\mathrm{N}$ is more, the crop would have a tendency to absorb more $\mathrm{P}$ and $\mathrm{K}$. This is in line, these findings are in accord with those of (Kumar Dubey et al 2012).

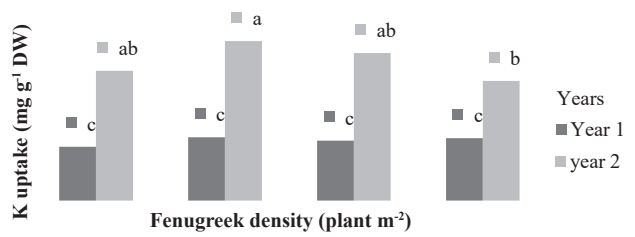

Figure 3- The interaction effect of year and fenugreek on $\mathrm{K}$ uptake of onion

B. Fenugreek, The result revealed that the effect of onion and fenugreek density were significant 
Table 6- The effect of intercropping onion with fenugreek on the N, P and $K$ uptake at two years

\begin{tabular}{llll}
\hline \multirow{2}{*}{$\begin{array}{l}\text { Treatments } \\
\text { (Onion: Fenugreek) }\end{array}$} & Mean of two years $N$ & Mean of two years $P$ & Mean of two years $K$ \\
\cline { 2 - 4 } Density 30 & $18.91 \mathrm{~cd}$ & $3.05 \mathrm{~cd}$ & $24.22 \mathrm{c}$ \\
Density 30: 25 & $26.14 \mathrm{a}$ & $4.67 \mathrm{a}$ & $38.02 \mathrm{a}$ \\
Density 30: 15 & $25.77 \mathrm{a}$ & $4.00 \mathrm{abc}$ & $35.19 \mathrm{a}$ \\
Density 30: 12 & $25.20 \mathrm{ab}$ & $4.13 \mathrm{ab}$ & $31.81 \mathrm{ab}$ \\
Density 25 & $18.80 \mathrm{~cd}$ & $2.97 \mathrm{~cd}$ & $23.88 \mathrm{c}$ \\
Density 25: 25 & $24.70 \mathrm{ab}$ & $3.73 \mathrm{abc}$ & $32.22 \mathrm{ab}$ \\
Density 25: 15 & $24.49 \mathrm{ab}$ & $3.86 \mathrm{abc}$ & $35.96 \mathrm{a}$ \\
Density 25: 12 & $20.58 \mathrm{bc}$ & $3.33 \mathrm{bcd}$ & $31.35 \mathrm{ab}$ \\
Density 20 & $14.99 \mathrm{~d}$ & $2.63 \mathrm{~d}$ & $22.11 \mathrm{c}$ \\
Density 20: 25 & $21.73 \mathrm{abc}$ & $3.66 \mathrm{abc}$ & $31.97 \mathrm{ab}$ \\
Density 20: 15 & $22.51 \mathrm{abc}$ & $3.69 \mathrm{abc}$ & $32.14 \mathrm{ab}$ \\
Density 20: 12 & $18.19 \mathrm{~cd}$ & $2.95 \mathrm{~cd}$ & $25.84 \mathrm{bc}$ \\
\hline
\end{tabular}

Means with similar letter in each column are not significantly $(\mathrm{P}<0.05)$ different by Duncan Multiple Range test

on mineral content and total mineral uptake of fenugreek $(\mathrm{P} \leq 0.01)$ in intercropping of onion and fenugreek. Fenugreek means comparisons (Table 7) revealed that the highest uptake plant $\mathrm{ha}^{-1}$ was related to 25 plants $\mathrm{m}^{-2}$ density and there was no significant difference in content and uptake by plant among fenugreek treatments. In intercropping system, the maximum mineral content of fenugreek was obtained under mono cropping (sole fenugreek), while no significant difference was observed in intercropping treatments. In contrast, the minimum total mineral uptake of fenugreek was obtained under mono cropping (sole fenugreek), while there was no significant difference in uptake among intercropping treatments (Table 7). Also, effects of onion and fenugreek densities interactions were significant on $\mathrm{P}$ and $\mathrm{K}$ uptake of fenugreek $(\mathrm{P} \leq 0.05)$. The highest fenugreek $\mathrm{P}$ and $\mathrm{K}$ uptake were observed

Table 7- The effect of intercropping of onion and fenugreek on the mineral content and total mineral uptake of fenugreek

\begin{tabular}{ccccccc}
\hline \multirow{2}{*}{$\begin{array}{c}\text { Density } \\
\left.\text { plants } \mathrm{m}^{-2}\right)\end{array}$} & \multicolumn{3}{c}{ Concentration $\left(\mathrm{mg} \mathrm{g}^{-1} \mathrm{DW}\right)$} & \multicolumn{4}{c}{ Uptake $\left(\mathrm{mg}\right.$ DW Plant $\left.{ }^{-1}\right)$} \\
\cline { 3 - 7 } Fenugreek & & $P$ & $K$ & $N$ & $P$ & $K$ \\
25 & $4.69 \mathrm{a}$ & $0.79 \mathrm{a}$ & $7.71 \mathrm{a}$ & $18.10 \mathrm{a}$ & $3.04 \mathrm{a}$ & $29.75 \mathrm{a}$ \\
15 & $4.81 \mathrm{a}$ & $0.77 \mathrm{a}$ & $7.93 \mathrm{a}$ & $15.65 \mathrm{a}$ & $2.58 \mathrm{a}$ & $26.15 \mathrm{a}$ \\
12 & $4.79 \mathrm{a}$ & $0.78 \mathrm{a}$ & $7.96 \mathrm{a}$ & $19.50 \mathrm{a}$ & $3.24 \mathrm{a}$ & $32.87 \mathrm{a}$ \\
\hline Onion & & & & & & \\
0 & $5.15 \mathrm{a}$ & $0.84 \mathrm{a}$ & $8.43 \mathrm{a}$ & $12.90 \mathrm{~b}$ & $2.12 \mathrm{~b}$ & $21.20 \mathrm{~b}$ \\
30 & $4.56 \mathrm{~b}$ & $0.77 \mathrm{~b}$ & $7.63 \mathrm{~b}$ & $18.94 \mathrm{a}$ & $3.10 \mathrm{a}$ & $31.32 \mathrm{a}$ \\
25 & $4.63 \mathrm{~b}$ & $0.75 \mathrm{~b}$ & $7.71 \mathrm{~b}$ & $19.91 \mathrm{a}$ & $3.35 \mathrm{a}$ & $34.01 \mathrm{a}$ \\
20 & $4.72 \mathrm{~b}$ & $0.76 \mathrm{~b}$ & $7.70 \mathrm{~b}$ & $19.31 \mathrm{a}$ & $3.25 \mathrm{a}$ & $31.83 \mathrm{a}$ \\
\hline
\end{tabular}

Means with similar letter in each column are not significantly $(\mathrm{P}<0.05)$ different by Duncan Multiple Range test 
in intercropping with 15:25 (fenugreek: onion) densities, while the lowest fenugreek $\mathrm{P}$ and $\mathrm{K}$ uptake were recorded mono cropping (sole onion) (Figure 4 and 5). Legumes are distinguished to fix atmospheric nitrogen into the soil, thus enriching soil fertility, and help to satisfy the $\mathrm{N}$ needs of cereals. Fenugreek being leguminous crops did not compete with onion for $\mathrm{N}$ for its growth and development besides, fixing of atmospheric $\mathrm{N}$ in soil. Also, onion and fenugreek have different root depths and architectures as well as different requirements for soil $\mathrm{N}, \mathrm{P}$ and $\mathrm{K}$. Fenugreek roots act as a source of nitrogen for plant as a result enriches the soil with nitrogen. Therefore, increase in the nutrient concentration of fenugreek was associated with increase in uptake of these nutrients in fenugreek. This can again be supported by synergistic uptake mechanism of $\mathrm{N}, \mathrm{P}$ and $\mathrm{K}$ and their assimilation which is manifested in the form of increase in yield along with higher nutritional demand for plant growth. These results are in close conformity with findings of (Tuncturk et al 2011).

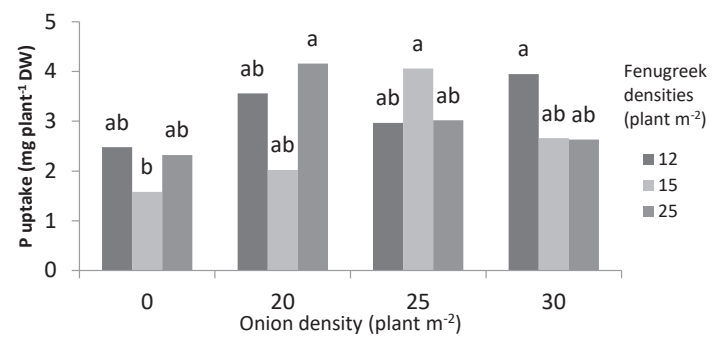

Figure 4- The interaction effect of onion and fenugreek on $P$ uptake of fenugreek

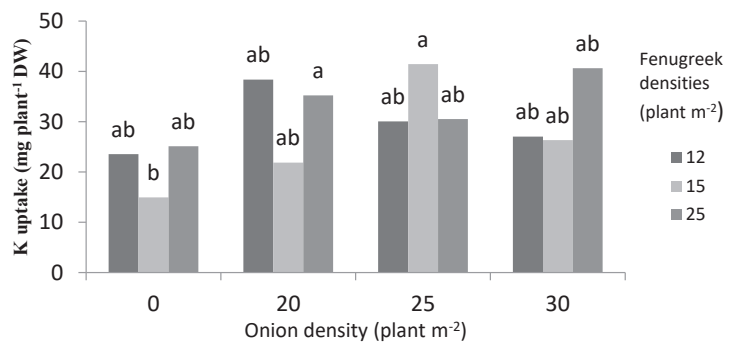

Figure 5- The interaction effect of onion and fenugreek on $\mathrm{K}$ uptake of fenugreek

\section{Conclusions}

This study was conducted in order to evaluate the effects of densities of onion and fenugreek in mono cropping and intercropping systems. According to the results, indicated that the mineral content and total mineral uptake by onion was increased when onion was intercropped with fenugreek. Therefore, the onion-fenugreek intercrop would be suitable to small-scale farmers who do not have adequate resources for purchase of chemical nutrients. The system would also be very ideal for organic vegetable production, in which chemical application is not desirable.

\section{References}

Abd EL-Gaid M A, AL-Dokeshy M H \& Nassef M T (2014). Effect of intercropping system of tomato and common bean on growth, yield components and land equivalent ratio in Newvally Gavernorate. Asian Journal of crop Science 6(3): 254-261

Alam N, Abadi A L, Rayes M L \& Zubaidah E (2016). Impact of inorganic, organic fertilizer and mulch to the physical and chemical characteristics of soil and production of red onion of Palu Valley Variety. Journal of Farming and Allied Sciences 5(5): 372-381

Anthon G E \& Barrett D M (2003). Modified method for the determination of pyruvic acid with dinitrophenylhydrazine in the assessment of onion pungency. Journal of the Science of Food and Agriculture 83(12): 1210-1213

Baethgen W E \& Alley M M (1989). A manual colorimetric procedure for measuring ammonium nitrogen in soil and plant kjeldahl digests. Communications in Soil Science and Plant Analysis 20: 961-969

Banik P, Midya A, Sarkar B K \& Ghose S S (2006). Wheat and chickpea intercropping systems in an additive series experiment. European Journal of Agronomical 24: $325-332$

Basch E, Ulbricht C, Kuo G, Szapary P \& Smith M (2003). Therapeutic applications of fenugreek. Alternative Medicine Review 8: 20-27

Brewester J L (1994). Onions and other vegetable Alliums. Wallingford, UK, pp. 236

Camilia Y (2001). Environmental risks of fertilizer use under Egyptian conditions. PhD Thesis. Ain Shams University. Egypt 
Cottenie A (1980). Soil and Plant Testing. FAO Soils Bulletin 38: 94-100

Gahoonia T S, Ali R, Malhotra R S, Jahoor A \& Rahman M M (2006). Variation in root morphological and physiological traits and nutrient uptake of chickpea genotypes. Journal of Plant Nutrition 29: 1-17

Hauggaard-Nielsen H, Ambus P \& Jensen E S (2003). The comparison of nitrogen use and leaching in sole cropped versus intercropped pea and barley. Nutrient Cycling in Agroecosystems 65: 289-300

Jackson L E, Pascual U \& Hodgkin T (2007). Utilizing and conserving agrobiodiversity in agricultural landscapes. Agriculture Ecosystem and Environment 121: 196-210

Kamran Khan M, Shahid Ibni Zamir M, Haq I, Zaman Q, Zohaib A \& Hussain S (2015). Barley intercropped with fenugreek yields more benefit under semi-arid Conditions of Pakistan. Research Journal of Fisheries and Hydrobiology 10(13): 1-7

Kumar Dubey P, Pandey C S, Shakoor Khanday A B \& Mishra G (2012). Effect of integrated nutrient management on nutrient uptake, protein content and yield of fenugreek. International Journal of Food 2(1): $1-12$

Li H, Shen J, Zhang F, Marschner P, Cawthray G \& Rengel Z (2010). Phosphorus uptake and rhizosphere properties of intercropped and mono cropped maize, faba bean, and white lupin in acidic soil. Biology and Fertility of Soils 46(2): 79-91

Lithourgidis A, Dordas C \& Vlachostergios D (2011). Annual intercrops: an alternative path way for sustainable agriculture. Australian Journal of Crop Science 5(4): 389-396

Malavolta E (2006). Manual de nutrição mineral de plantas. Agronômica Ceres. 638 pp

Myaka F M, Sakala W D, Adu-Gyamfi J J, Kamalongo D, Ngwira N, Odgaard R, Nielsen N E \& Høgh-Jensen H (2006). Yields and accumulation of $\mathrm{N}$ and $\mathrm{P}$ in farmermanaged intercrops of maize-pige on pea in semi-arid Africa. Plant Soil 285: 207-220

Oroka F O \& Omoregie A (2007). Competition in a ricecowpea intercrope as affected by nitrogen fertilizer and plant population. Science Agriculture 64(6): 621629

Ouma G \& Jeruto P (2010). Sustainable horticultural crop production through intercropping: The case of fruits and vegetable crops: A review. Agriculture and Biology Journal of North America 1(5): 1098-1105
Owusu A \& Sadick A (2016). Assessment of soil nutrients under maize intercropping system involving soybean. Research Journal of Agricultural and Food Sciences 1(3): 33-43

Parsons A N, Welker J M \& Wookey P A (1994). Growth responses of four sub-arctic dwarf shrubs to simulated environmental change. Journal of Ecology 82: 307318

Pozdíšek J, Henriksen B, Ponížil A \& Løes A K (2011). Utilizing legume- cereal intercropping for increasing selfsufficiencyon organic farms in feed for monogastricanimals. Agronomy Research 9(1-2): 343-356

Raj N \& Yadav D S (2005). Advances in vegetable production. New Delhi Research Co. Book Center. $995 \mathrm{pp}$

Rathika S (2013). Effect of crop geometry, intercropping and topping practices on yield, nutrient uptake and soil fertility status of baby corn (Zea mays L.). International Journal of Agricultural Sciences 9(2): 583-587

Risser P G (1985). Toward a holistic management perspective. BioScience 35: 414-418

Thavaprakaash N \& Velayudham K (2007). Effect of crop geometry, intercropping systems and INM practices on cob yield and nutrient uptake of baby corn. Asian Journal Agriculture Research 1: 10-16

Tuncturk R, Celen A E \& Tuncturk M (2011). The effect of nitrogen and sulphur fertilizers on the yield and quality of fenugreek (Trigonella foenum -graecum L.). Turkesh Journal of Field Crops 16: 69-75

Wasaya A, Ahmad R, Hassan F U, Ansar M, Manaf A \& Sher A (2013). Enhancing crop productivity through Wheat (Triticum aestivum L.) - Fenugreek intercropping system. The Journal of Animal and Plant Sciences 23(1): 210-215

Zhang J E, Gao A X, Xu H Q \& Luo M Z (2009). Effects of maize/peanut intercropping on rhizosphere soil microbes and nutrient contents. Journal of Applied Ecology 20: 1597-1602

Zhang X, Huang G, Bian X \& Zhao Q (2013). Effects of root interaction and nitrogen fertilization on the root activity, photosynthetic characteristic so intercropped soybean and microbial quantity in the rhizosphere. Plant Soil Environment 59(2): 80-88 